\title{
Solvent-Free Synthesis of $\alpha$-Amino Nitrile-Derived Ureas
}

Pilar Ventosa-Andrés, Juan A. González-Vera, M. Teresa García-López, and Rosario Herranz*

Instituto de Química Médica (CSIC), Juan de la Cierva 3, 28006

Madrid, Spain

rosario@iqm.csic.es

Received Date (will be automatically inserted after manuscript is accepted)

\section{ABSTRACT}

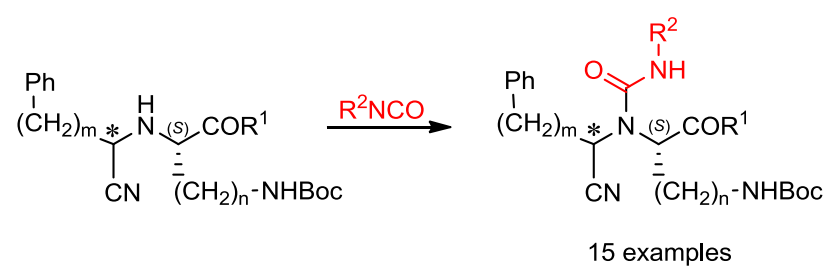

An efficient and environmentally friendly methodology for the solvent-free synthesis of $\alpha$-amino nitrile-derived ureas from $\alpha$-amino acid-based amino nitriles has been developed. At room temperature no epimerization was observed in the resulting ureas, but under MW heating, epimerization occurred at the chiral center bearing the cyano group.

* Corresponding author. Tel.: +34-912587537; fax: +34-915644853; e-mail: rosario@iqm.csic.es 
$\alpha$-Amino nitriles are versatile intermediates for the synthesis of multiple building blocks. ${ }^{1}$ In particular, $\alpha-$ amino acid-derived amino nitriles have shown high potential for molecular diversity generation. ${ }^{2}$ Thus, we have shown their utility in the synthesis of pseudopeptides $^{3}$ and diverse chiral heterocyclic compounds. ${ }^{4}$

Among $\alpha$-amino nitrile derivatives, $N$-acyl-aminonitriles have shown to be privileged molecules for the search of inhibitors of therapeutically important peptidases, ${ }^{5}$ such as dipeptidyl peptidase $\mathrm{IV}^{6}{ }^{6}$ prolyl oligopeptidases, ${ }^{7}$ and cysteine cathepsins. $^{8}$ More concretely, several $\alpha$-amino nitrile-derived ureas have been patented as inhibitors of cholesteryl ester transfer protein $^{9}$ and diverse enzymes, ${ }^{10}$ agents for neurological disorders, ${ }^{11}$ pesticides, ${ }^{12}$ or fungicides. ${ }^{13}$ On the other hand, $\alpha$-amino nitrile-derived ureas are intermediates in the synthesis of diverse pharmacologically active hydantoin derivatives from $\alpha$-amino nitriles, ${ }^{14}$ although these intermediates have not been isolated and characterized. Therefore, to develop simple and versatile methods for the synthesis and identification of $\mathrm{N}$ (cyanomethyl)ureas is an important goal in synthetic organic chemistry, in particular, environmentally friendly solvent-free procedures.

In the context of a medicinal chemistry project focused on the search of modulators of protein-protein interactions, we required the basic amino acid-derived $\mathrm{N}$ (cyanomethyl)ureas of general formula A (Scheme 1), which were expected to be easily accessible from the corresponding $\alpha$-amino nitriles $\mathbf{B}$, by reaction with isocyanates. These $\alpha$-amino nitriles $\mathbf{B}$ were previously obtained by a modified Strecker synthesis as epimeric mixtures in the carbon bearing the cyano group, which were chromatographically resolved. ${ }^{15}$

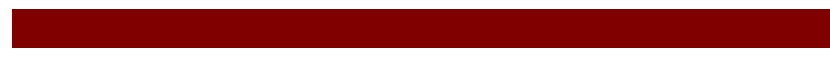

Scheme 1
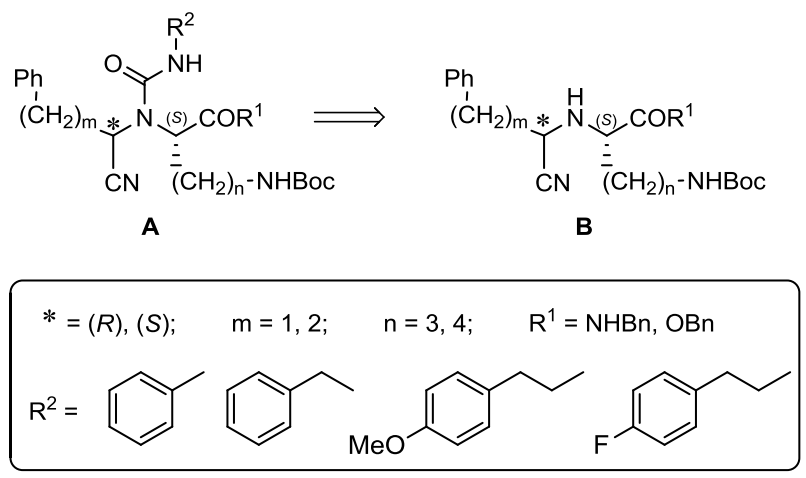

The reaction of the $\alpha$-amino nitrile (S)-1a (Scheme 2) with two equivalents of phenyl isocyanate was used for setting up the methodology. Initially, the synthesis of the $N$-(cyanomethyl)urea $(\boldsymbol{S})-\mathbf{2}$ a was explored in parallel in two different solvents, in $\mathrm{CH}_{2} \mathrm{Cl}_{2}$ at room temperature and in THF at $0{ }^{\circ} \mathrm{C}$, under described reaction conditions. ${ }^{14 a, 16}$ When the reaction was carried out in THF, $86 \%$ of urea (S)-2a was isolated after 3 days of reaction. However, in the case of the reaction in $\mathrm{CH}_{2} \mathrm{Cl}_{2}$, after 5 days, the starting amino nitrile $(\boldsymbol{S})$-1a remained unaltered, but, after 3 additional days, when the solvent had accidentally evaporated, the TLC and HPLC analysis of the crude reaction mixture showed the presence of $60 \%$ of $(S)$-2a. This result induced us to study the reaction under solventfree conditions. These involved the mixture and homogenization of reagents with a minimum amount of dry $\mathrm{CH}_{2} \mathrm{Cl}_{2}$, followed by evaporation of the solvent under argon. As shown in Table 1, under these conditions, a 98 $\%$ of the wished urea $(\boldsymbol{S})$-2a was obtained after $48 \mathrm{~h}$.

Scheme 2. Synthesis of the $N$-(cyanomethyl)ureas 2a from the $\alpha$-amino nitrile $(\boldsymbol{S})$-1a as indicated in Table 1

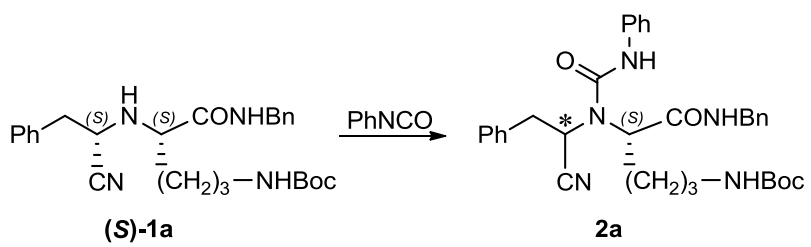

Table 1. Influence of reaction conditions on the synthesis of the $N$-(cyanomethyl)ureas $\mathbf{2 a}$

\begin{tabular}{|c|c|c|c|c|c|c|}
\hline \multirow[b]{2}{*}{ entry } & \multirow{2}{*}{$\begin{array}{c}\text { amino nitrile } \\
\mathrm{n}^{\mathrm{o}}\end{array}$} & \multirow[b]{2}{*}{ solvent } & \multirow[b]{2}{*}{$t\left({ }^{\circ} \mathrm{C}\right)$} & \multirow[b]{2}{*}{$t$} & \multicolumn{2}{|c|}{ (cyanomethyl)urea } \\
\hline & & & & & $\mathrm{n}^{\mathrm{o}}$ & $(\%)^{a}$ \\
\hline 1 & $(S)-1 \mathbf{a}$ & THF & 0 & $3 \mathrm{~d}$ & $(S)-2 a$ & 86 \\
\hline 2 & $(S)-1 \mathbf{a}$ & $\mathrm{CH}_{2} \mathrm{Cl}_{2}$ & $\mathrm{rt}$ & $5 \mathrm{~d}$ & $(S)-2 \mathbf{a}$ & 0 \\
\hline 3 & $(S)-1 \mathbf{a}$ & - & $\mathrm{rt}$ & $\begin{array}{c}48 \\
h\end{array}$ & $(S)-2 \mathbf{a}$ & 98 \\
\hline $4^{b}$ & $(S)-1 \mathbf{a}$ & $\mathrm{CH}_{2} \mathrm{Cl}_{2}$ & 80 & $2 \mathrm{~h}$ & $(S)-\mathbf{2 a}$ & 0 \\
\hline $5^{b}$ & $(S)-1 \mathbf{a}$ & - & 80 & $2 \mathrm{~h}$ & $(R S)-2 a$ & $98^{c}$ \\
\hline $6^{b}$ & $(R)-1 \mathbf{a}$ & - & 80 & $2 \mathrm{~h}$ & $(R S)-2 \mathrm{a}$ & $98^{c}$ \\
\hline
\end{tabular}

Next, with the aim of decreasing the reaction time, the reaction was carried out under heating at $80{ }^{\circ} \mathrm{C}$ by microwave irradiation. When this heating was applied using $\mathrm{CH}_{2} \mathrm{Cl}_{2}$ as solvent, the starting amino nitrile $(\boldsymbol{S})$-1a was recovered unaltered after $2 \mathrm{~h}$ (Table 1 , entry 4 ). However, when the microwave heating was applied to the solvent-free reaction mixture, a $98 \%$ of the epimeric mixture of ureas $(\boldsymbol{R S})-\mathbf{2 a}$ was obtained. A similar result was obtained when the starting amino nitrile was the epimer ( $\boldsymbol{R})$-1a (Table 1, entry 6). In both cases, the HPLC analysis of the crude reaction mixture showed the presence of the two epimeric ureas $(\boldsymbol{R})$ - and $(\boldsymbol{S})$-2a with $t_{\mathrm{R}}$ of 27.7 and $27.5 \mathrm{~min}$, respectively, in an $\approx 1: 1$ ratio and traces of the corresponding starting amino nitrile $(\boldsymbol{R})$ - or 
$(\boldsymbol{S})$-1a at 23.28 or $23.89 \mathrm{~min}$. These data indicated epimerization in the (cyanomethyl)urea at the carbon bearing the cyano group, which had not occurred in the starting amino nitriles $(\boldsymbol{R})$ - and $(\boldsymbol{S})$-1a. These results were confirmed in the ${ }^{1} \mathrm{H}$ NMR analysis of the crude reaction products. As shown in Scheme 3, the higher propensity of $N$-(cyanomethyl)ureas to epimerize, with respect to the corresponding $\alpha$-amino nitrile, could be explained due to the electron attracting effect of the ureido group, which would increase the acidity of the proton in position $\alpha$ to the cyano group, facilitating the formation of the tautomeric ketimine species 3a, which would revert to give the epimeric mixture of $N$-(cyanomethyl)ureas (RS)2a. Both pure isolated epimers $(\boldsymbol{R})$ - and $(\boldsymbol{S})$-2a epimerized by heating at $80{ }^{\circ} \mathrm{C}$ under $\mathrm{MW}$ irradiation, although this epimerization was slower in $(\boldsymbol{S})$-2a than in (R)-2a (180 vs. $120 \mathrm{~min}$ for complete epimerization).
However, under similar conditions, the starting amino nitriles $(\boldsymbol{R})$ - and $(\boldsymbol{S})$-1a were recovered without epimerization. In relation to these results, two recent reports, on the enzymatic resolution of $\alpha$-amino nitriles, reported the complete racemization of $\alpha$-acylamino nitriles at $40{ }^{\circ} \mathrm{C}$, while no racemization at all was observed in their respective $\alpha$-amino nitriles. ${ }^{17}$ After chromatographic resolution of the epimeric mixtures $(\boldsymbol{R S})$-2a, each of the resulting epimer showed the same optical rotation as $(\boldsymbol{R})$-2a and $(\boldsymbol{S})$-2a obtained under free epimerization conditions. This result indicated that epimerization had taken place at the carbon bearing the cyano group and not at the carbon bearing the $N$-benzyl carboxamide group, as in that case the epimerization compounds would be enantiomers of $(\boldsymbol{R})$-2a and $(S)$-2a with the same optical rotation value, but opposite sign.

Scheme 3. Proposed mechanism of epimerization of N-(cyanomethyl)ureas

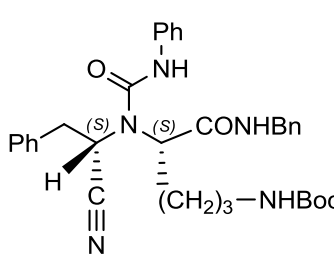

(S)-2a

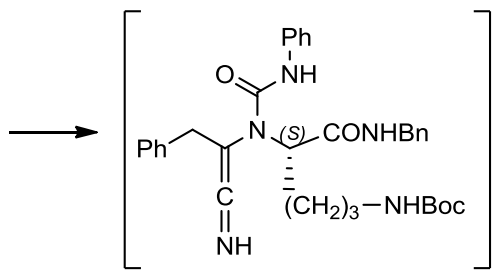

$3 a$

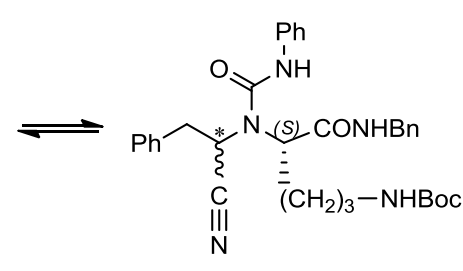

(RS)-2a
In view of the results shown in Table 1, we considered that the best conditions for the epimerization-free synthesis of $\mathrm{N}$-(cyanomethyl)ureas from $\alpha$-amino nitriles were the solvent-free reaction with two equivalents of isocyanate at room temperature. These conditions were applied for the synthesis of ureas 2a-d and 4-6a as shown in Scheme 4 and Table 2. When, due to problems of resolution, the starting $\alpha$-amino nitrile was an epimeric mixture, to optimize the reaction time, the synthesis was carried out under MW irradiation.

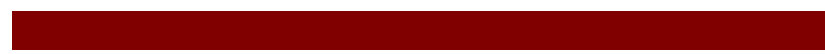

Scheme 4

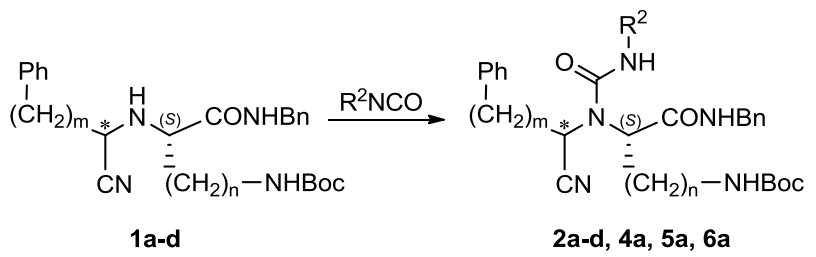

a: $m=1, n=3 ; \quad$ b: $m=1, n=4 ; \quad$ : $m=2, n=3 ; \quad d: m=2, n=4$
Table 2. Synthesis of $N$-(cyanomethyl)ureas 2a-d from $\alpha$ amino nitriles 1a-d

\begin{tabular}{|c|c|c|c|c|c|}
\hline \multicolumn{3}{|c|}{$\alpha$-amino nitrile } & \multicolumn{3}{|c|}{ (cyanomethyl)urea } \\
\hline entry & $\mathrm{N}^{\mathrm{o}}$ & method $^{a}$ & $\mathrm{~N}^{\mathrm{o}}$ & $\mathrm{R}^{2}$ & $(\%)^{b}$ \\
\hline 1 & $(R)-1 \mathbf{a}$ & B & $(R)-2 \mathbf{a}$ & $\mathrm{Ph}$ & 96 \\
\hline 2 & $(S)-1 \mathbf{a}$ & B & $(S)-2 \mathbf{a}$ & $\mathrm{Ph}$ & 86 \\
\hline 3 & $(\boldsymbol{R S})-\mathbf{1} \mathbf{a}^{c}$ & $\mathrm{C}$ & $(R S)-2 a$ & $\mathrm{Ph}$ & 95 \\
\hline 4 & $(R)-1 \mathbf{a}$ & B & $(R)-4 a$ & $\mathrm{Bn}$ & 95 \\
\hline 5 & $(S)-1 a$ & B & $(S)-4 a$ & $\mathrm{Bn}$ & 93 \\
\hline 6 & $(\boldsymbol{R S})-\mathbf{1} \mathbf{a}^{c}$ & $\mathrm{C}$ & $(R S)-4 a$ & $\mathrm{Bn}$ & 97 \\
\hline 7 & $(R)-1 \mathbf{a}$ & $\mathrm{B}$ & $(R)-5 a$ & 4-MeO-Ph- $\left(\mathrm{CH}_{2}\right)_{2}$ & 94 \\
\hline 8 & $(S)-1 \mathbf{a}$ & B & $(S)-5 a$ & 4-MeO-Ph- $\left(\mathrm{CH}_{2}\right)_{2}$ & 93 \\
\hline 9 & $(\boldsymbol{R S})-\mathbf{1} \mathbf{a}^{c}$ & $\mathrm{C}$ & $(R S)-5 a$ & 4-MeO-Ph- $\left(\mathrm{CH}_{2}\right)_{2}$ & 90 \\
\hline 10 & $(S)-1 \mathbf{a}$ & B & $(S)-6 a$ & 4-F-Ph- $\left(\mathrm{CH}_{2}\right)_{2}$ & 91 \\
\hline 11 & $(\boldsymbol{R S})-\mathbf{1} \mathbf{a}^{c}$ & $\mathrm{C}$ & $(R S)-6 a$ & 4-F-Ph- $\left(\mathrm{CH}_{2}\right)_{2}$ & 96 \\
\hline 12 & $(R S)-1 b^{d}$ & $\mathrm{C}$ & $(R S)-2 b$ & $\mathrm{Ph}$ & 95 \\
\hline 13 & $(\boldsymbol{R S})-\mathbf{1} \mathbf{c}^{c}$ & $\mathrm{C}$ & $(R S)-2 c$ & $\mathrm{Ph}$ & 92 \\
\hline 14 & $(R S)-1 d^{c}$ & $\mathrm{C}$ & $(R S)-2 d$ & $\mathrm{Ph}$ & 97 \\
\hline \multicolumn{6}{|c|}{$\begin{array}{l}{ }^{a} \text { Method B: Solvent-free, rt, } 2-3 \text { days; Method C: MW } 80{ }^{\circ} \mathrm{C}, 2-3 \mathrm{~h} . \\
{ }^{b} \text { Isolated yield. }{ }^{c}[(R):(S)] \text { epimer ratio }=1: 1 .{ }^{d}[(R):(S)] \text { epimer ratio }= \\
1: 3 \text {. }\end{array}$} \\
\hline
\end{tabular}

The methodology was also applied to the methyl ester $\alpha$-amino nitriles $(\boldsymbol{R})$ - and $(\boldsymbol{S})-\mathbf{7} \mathbf{a}, \mathbf{b}$, derived from ornithine (a) and lysine (b) (Scheme 5). In these cases, the HPLC- 
MS analyses of the crude reaction mixtures indicated that the reactions were significantly slower and, after 7 days, they showed $75 \%$ of conversion to give $43 \%$ of the respective $N$-(cyanomethyl)urea $(\boldsymbol{R})$ - and $(\boldsymbol{S})-\mathbf{8 a}, \mathbf{b}$ along with $33 \%$ of the corresponding hydantoin derivative $(\boldsymbol{R})$ and $(\boldsymbol{S})-9 \mathbf{a}, \mathbf{b}$. However, when the reactions were carried out under $\mathrm{MW}$ irradiation at $80^{\circ} \mathrm{C}$, after $2 \mathrm{~h}$, the HPLC-
MS analyses of the crude reaction mixtures showed the formation of a $90 \%$ of ureas $(\boldsymbol{R})$ - and $(\boldsymbol{S})-\mathbf{8 a}, \mathbf{b}$, and traces of the corresponding hydantoin. After silica gel column chromatography, the ureas cyclized completely to the respective hydantoin derivatives $(\boldsymbol{R})$ - and $(\boldsymbol{S})-\mathbf{9 a}, \mathbf{b}$, which were isolated free of epimerization in 70-78 \% yield.

\section{Scheme 5}

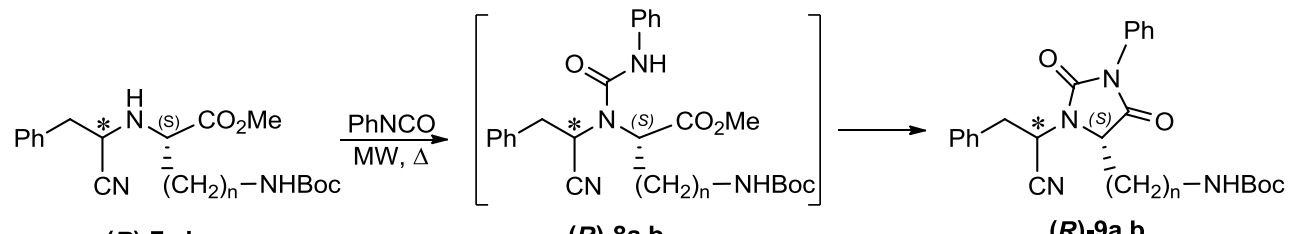

$\begin{array}{ll}(R)-7 \mathrm{a}, \mathrm{b} & (R)-8 \mathrm{a}, \mathrm{b} \\ (S)-7 \mathrm{a}, \mathrm{b} & (S)-8 \mathrm{a}, \mathrm{b}\end{array}$

(R)-9a,b

(S) $-9 \mathrm{a}, \mathrm{b}$

a: $n=3 ; \mathbf{b}: n=4$

In conclusion, we have developed an environmentally friendly solvent-free methodology for the synthesis of amino acid-based chiral highly functionalized $\mathrm{N}$ (cyanomethyl)ureas with high potential for the generation of molecular diversity in drug discovery. Although the synthesis can be activated by MW heating, precaution must be taken as it can induce epimerization at the chiral center bearing the cyano group.

Acknowledgment. This work was supported by the Spanish Ministerio de Ciencia e Innovación grant SAF2009-09323. P. V.-A. held a FPI fellowship from the Ministerio de Ciencia e Innovación.

Supporting Information Available. Detailed experimental procedures and full characterization for new compounds are provided in the Supporting Information. This material is available free of charge via the internet at http://pubs.acs.org.

(1) (a) Enders, D.; Shilvock, J. P. Chem. Soc. Rev. 2000, 29, 359-373. (b) Wang, J.; Liu, X.; Feng, X. Chem. Rev. 2011, 111, 6947-6983.

(2) González-Vera, J. A.; García-López, M. T.; Herranz, R. Mini-Rev. Org. Chem. 2008, 5, 209-221.

(3) (a) Herranz, R.; Suárez-Gea, M. L.; Vinuesa, S.; García-López, M. T. J. Org. Chem. 1993, 58, 5186-5191. (b) Herrero, S.; Suárez-Gea, M. L.; González-Muñiz, R.; García-López, M. T.; Herranz, R.; Ballaz, S.; Barber, A.; Fortuño, A.; Del Río, J. Bioorg. Med. Chem. Lett. 1997, 7, 855-860.

(4) (a) Herrero, S.; García-López, M. T.; Latorre, M.; Cenarruzabeitia, E.; Del Río, J.; Herranz, R. J. Org. Chem. 2002, 67, 3866-3873. (b) Herrero, S.; García-López, M. T.; Herranz, R. J. Org. Chem. 2003, 68, 4582-4585. (c) Herrero, S.; Salgado, A.; García-López, M. T.; Herranz, R. Tetrahedron Lett. 2002, 43, 4899-4902. (d) González-Vera, J. A.; García-López, M. T.; Herranz, R. J. Org. Chem. 2005, 70, 3660-3666. (e) González-Vera, J. A.; García-López, M. T.; Herranz, R. Org. Lett. 2004, 6, 2641-2644.
(5) Fleming, F. F.; Yao, L.; Ravikumar, P. C.; Funk, L.; Shook, B. C. J. Med. Chem. 2010, 53, 7902-7917.

(6) (a) Weber, A. E. J. Med. Chem. 2004, 47, 4135-4141. (b) Pei, Z. Curr. Opin. Drug Discov. Devel. 2008, 11, 512-32.

(7) Lawandi, J.; Gerber-Lemaire, S.; Juillerat-Jeanneret, L.; Moitessier, N. J. Med. Chem. 2010, 53, 3423-38.

(8) (a) Frizler, M.; Stirnberg, M.; Sisay, M. T.; Gütschow, M. Curr. Top. Med. Chem. 2010, 10, 294-322. (b) Wijkmans, J.; Gossen, J. Expert. Opin. Ther. Pat. 2011, 21, 1611-29.

(9) Salvati, M. E.; Finlay, H.; Harikrishnan, L. S.; Jiang, J.; Johnson, J. A.; Kamau, M. G.; Lawrence, R. M.; Miller, M. M.; Qiao, J. X.; Wang, T. C.; Wang, Y.; Yang, W. WO2007062314A2, 2007.

(10) (a) Matsuno, K.; Ueno, K.; Iwata, Y.; Matsumoto, Y.; Nakanishi, S.; Tasaki, K.; Kusaka, H.; Nomoto, Y.; Ogawa, A. US20040180925A1, 2004. (b) Bloomfield, G. C.; Bruce, I.; Hayler, J. F.; Leblanc, C.; Le, G. D. M.; McCarthy, C. WO2005021519A2, 2005.

(11) Ross, D. T.; Sauer, H.; Hamilton, G. S.; Steiner, J. P. WO2000009106A2, 2000.

(12) Pazenok, S.; Krautstrunk, G.; Lantzsch, R. WO2005035508A2, 2005.

(13) Schulze, W.; Klepel, M.; Jumar, A.; Lehmann, H.; Braemer, B. DD232636A1, 1986.

(14) (a) Rowbottom, M. W.; Vickers, T. D.; Tamiya, J.; Zhang, M.; Dyck, B.; Grey, J.; Schwarz, D.; Heise, C. E.; Hedrick, M.; Wen, J.; Tang, H.; Wang, H.; Fisher, A.; Aparicio, A.; Saunders, J.; Goodfellow, V. S. Bioorg. Med. Chem. Lett. 2007, 17, 2171-2178. (b) Coburn, C. A.; Egbertson, M. S.; Graham, S. L.; McGaughey, G. B.; Stauffer, S. R.; Rajapakse, H. A.; Nantermet, P. G.; Stachel, S. R.; Yang, W.; Lu, W.; Fahr, B. WO2007011833A2, 2007. (c) Coburn, C. A.; Egbertson, M. S.; Graham, S. L.; McGaughey, G. B.; Stauffer, S. R.; Yang, W.; Lu, W.; Fahr, B. WO2007011810A1, 2007. (d) Jung, M. E.; Ouk, S.; Yoo, D.; Sawyers, C. L.; Chen, C.; Tran, C.; Wongvipat, J. J. Med. Chem. 2010, 53, 2779-2796. (e) Sacchetti, A.; Silvani, A.; Gatti, F. G.; Lesma, G.; Pilati, T.; Trucchi, B. Org. Biomol. Chem. 2011, 9, 5515-5522.

(15) Ventosa-Andrés, P.; García-López, M. T.; Herranz, R. Tetrahedron: Asymmetry 2012, 23, 1198-1205.

(16) Bartolomé-Nebreda, J. M.; García-López, M. T.; GonzálezMuñiz, R.; Cenarruzabeitia, E.; Latorre, M.; Del Río, J.; Herranz, R. J. Med. Chem. 2001, 44, 4196-206.

(17) (a) Vongvilai, P.; Ramström, O. J. Amer. Chem. Soc. 2009, 131, 14419-14425. (b) Vongvilai, P.; Linder, M.; Sakulsombat, M.; Svedendahl Humble, M.; Berglund, P.; Brinck, T.; Ramström, O. Angew. Chem. Int. Ed. 2011, 50, 6592-6595. 